\title{
Attitudes of Students in Secondary School towards the Rules of Etiquette: A Study on Development of a Scale
}

\author{
Faruk Polatcan
}

Department of Turkish and Social Sciences Education, Faculty of Education, Atatürk University, Turkey

Copyright $₫ 2018$ by authors, all rights reserved. Authors agree that this article remains permanently open access under the terms of the Creative Commons Attribution License 4.0 International License

\begin{abstract}
The aim of this study is to develop a scale in order to determine the attitudes of students in secondary school towards etiquette. The working group of the study consisted of 266 students who have attended three secondary schools in Erzurum. Factor analysis has been carried out by the obtained data to ensure validity. As a result of the factor analysis, a structure consisting of two factors defined as "personal rules and social rules" which accounts for $52.25 \%$ of the total variance of the scale has been formed. The Cronbach alpha reliability coefficients have been calculated to determine the reliability of the scale. It has been found as 0.748 in the personal rules sub-dimension and 0.797 in the social rules sub-dimension.
\end{abstract}

Keywords Rules of Etiquette, Scale for Rules of Etiquette, Development of a Scale

\section{Introduction}

Human beings have formed rules to keep their lives together in a community as a society member. Some of these rules are constitution, law, regulation, etc., which are sharp, strict rules that provide state order, while the others which are approved by the society -such as good manners, courtesy, etc. - are softer set of rules that does not require sanctions and makes life easier.

The etiquette has been defined as "The behaviors and attitudes for the respect and kindness that exist in a society and discipline" [18] and it has been considered as "experience that obtained by an individual while living and experiencing inside life" [18]. And rules of etiquette are determined as "a set of rules, knowledge on behavior and etiquette which controls the behaviors and attitudes in a society or a community" [18].

As it has been mentioned, rules of proprieties in several fields in which range from eating and drinking to dressing up and greeting are the norms of behavioral rules related to the sociocultural conditions of the ways of life and beliefs of societies they belong to. These rules vary depending on time, space, and situation, but always regulate the relation between the individual with the individual and relation with the society (in the way of being better and more perfect) [1].

Rules of proprieties are not a list that has to be followed. On the contrary, it means living in a principled and meaningful way in accordance with the human nature. The propriety refers to aim at reaching good and pleasant one, instead of just living with obeying the rules. The beneficial sides of propriety rules are:

- It removes people from the simplicity and simple attitudes.

- It brings together with courtesy, kindness and the ability to think considerately.

- Etiquette requires to being tolerant and positive.

- It removes the roughness of the human spirit.

- It helps to be an individual to be a humane person.

- It makes easy to realize the details.

- It develops an individual's point of view towards life [5].

Individuals can become funny when they are overly adhering to the rules of etiquette. On the contrary, if they do not obey at all, mistakes and flaws that they made, and they do not like, may occur. The remedy that individuals find for these imperfections not to occur is "discipline, kindness and etiquette" [4].

When the rules of etiquette that the societies put forth by common consensus are followed, the individual has to be seen as "cultured", "gentle", "polite", "kind", "superior", "elite", "respectable", "affectionate" "civilized" "sympathetic", "contemporary", "modern", "privileged". In cases where they are not followed, they can be excluded from the society with the perception that they are regarded as "crude", "selfish", "tactless", "impolite", "disrespectful", "impudent", "impertinent", "thoughtless", "unfettered", "reckless", "rebellious" ignorant", "arrogant" and so on [1].

Considering the literature, it has been seen that the studies carried out are mostly in the form of lists to be 
followed. These are: [4], [5], [10], [11], [16]. In these studies, the famous Turkish thinkers Erzurumlu İbrahim Hakkı's Marifetname and Yusuf Has Hacib's Kutadgu Bilig about the rules of society and the level of overlap of the opinions of the prospective teachers about these rules were compared. In the end, both female and male prospective teachers who expressed the violence of thinkers against women and children were rejected. However, in the studies such as [1], [7], [8] etc. prospective teachers' attitudes toward etiquette has been examined. In this research, it has been tried to determine the attitudes of the secondary school students regarding the rules of etiquette.

\section{Method}

People are able to live as tops thanks to the rules. While we live by internalizing some of these rules, we can comply with others because of necessity. This scale was developed in order to determine the students' perspective on this rule.

This scale is a Likert measurement tool based on self-report and developed to determine the attitudes of secondary school students to the rules of etiquette. The scale consists of 17 items and 2 sub-dimensions. The information on the study group, its validity, its reliability and its development process has been mentioned below.

\subsection{Working Group}

Explanatory and confirmatory factor analyzes have been carried out to determine the factor structure of the scale. In order to make the analyzes, survey forms have been applied to the secondary school students, 142 females and 124 male students, in total 266 students who are attending to three secondary school in Palandöken district which is the central district of Erzurum province.

\subsection{Development of the Scale}

In order to form the item pool of Rules of Etiquette Scale, essays on the improper acts and behaviors that they have encountered in their daily life have been written by the students. The first form to be prepared by consulting five Turkish language education experts and item pool consists of 49 items has been obtained. Within a pilot scheme, the obtained item pool has been applied to 60 secondary school students. In the pilot application, the first scale form consisting of 26 items was obtained after the items with the item total correlation less than 0.40 and the items that were found to be incompatible with the scale have been excluded. The obtained form has been re-applied for factor analysis.

\section{Findings}

In this part, findings on the validity and reliability studies of the "Rules of Etiquette" have been stated.

\subsection{Findings Related to Validity}

Explanatory factor analysis (EFA) and confirmatory factor analysis (CFA) have been conducted to ensure the validity of the Scale for Rules of Etiquette. The EFA has been firstly carried out to examine the factor structure of the Scale for Rule of Propriety. As stated in [6], [14] literature, it has been considered that factor load value of the item in EFA is at least 0.40, the difference between factor load values of two items is at least 0.10 , and the eigenvalues are close to 1 . Seven items which have load values below 0.40 have been removed from the scale. In the analysis, Basic Component Analysis and Direct Oblimin rotation method have been applied.

Kaiser Meyer Olkin (KMO) and Bartlett tests have been applied in order to test the sample suitability of the collected data in the working group. Increases in significance in $\mathrm{KMO}$, greater than 0.60 , and a significant Bartlett test indicate that data is appropriate for factor analysis [12].

Table 1. KMO and Bartlett test results of the Scale for Rules of

\begin{tabular}{|c|c|c|}
\hline \multicolumn{2}{|c|}{ KMO Suitability Test } & 0.803 \\
\hline \multirow{3}{*}{$\begin{array}{c}\text { Bartlett's test of } \\
\text { sphericity }\end{array}$} & Estimated Chi-square & 728.702 \\
\cline { 2 - 3 } & Degree of Freedom & 136 \\
\cline { 2 - 3 } & Level of Significance & 0.000 \\
\hline
\end{tabular}

In table 1 , it has been shown that KMO result has been found as 0.803 and Bartlett test has been resulted as significant and these results indicates that the sample is appropriate with the factor analysis.

The distribution of the items of the scale according to dimensions, load values, variance ratios and total variance ratios as a result of EFA have been shown in Table 2.

As the result of the EFA is a 2-factor structure that accounts for $52.25 \%$ of the total variance has been obtained. The first of these is the personal rule sub-dimension consisting of $1^{\text {st }}, 5^{\text {th }}, 7^{\text {th }}, 8^{\text {th }}, 10^{\text {th }}, 11^{\text {th }}, 12^{\text {th }}, 13^{\text {th }}$ and $17^{\text {th }}$ items. The second is the social rule which consists of $2^{\text {nd }}$, $4^{\text {th }}, 3^{\text {rd }}, 6^{\text {th }}, 9^{\text {th }}, 14^{\text {th }}, 15^{\text {th }}$ and $16^{\text {th }}$ sub-dimensions.

It has been stated that the sub-limit of the item factor load values should be 0.32 [17]. It has been seen that the item factor load values in the Scale for Rules of Etiquette ranged from 0.35 to 0.78 .

Correlations between factors have been examined in order to determine the relation between the factors of the Scale for Rules of Etiquette. It has been recommended that the correlation between the sub-dimensions should be 0.90 and above to avoid the problem of multiple correlation [3] 
Table 2. Distribution of Rules of Etiquette by Factors, item factor loads and factor variances

\begin{tabular}{|c|c|c|}
\hline Items & $1^{\text {st }}$ Factor & $2^{\text {st }}$ Factor \\
\hline 8 & 0.785 & \\
\hline 1 & 0.624 & \\
\hline 12 & 0.544 & \\
\hline 5 & 0.519 & \\
\hline 17 & 0.513 & \\
\hline 11 & 0.506 & \\
\hline 10 & 0.392 & \\
\hline 7 & 0.391 & \\
\hline 13 & 0.353 & \\
\hline 4 & & 0.745 \\
\hline 3 & & 0.663 \\
\hline 15 & & 0.635 \\
\hline 6 & & 0.496 \\
\hline 14 & & 0.463 \\
\hline 16 & & 0.417 \\
\hline 9 & & 0.361 \\
\hline 2 & & 0.357 \\
\hline
\end{tabular}

Table 3. Correlation between sub-dimensions of the Scale for Rules of Etiquette

\begin{tabular}{|c|c|c|}
\hline & 1 & 2 \\
\hline 1 & 10.000 & \\
\hline 2 & -0.275 & 10.000 \\
\hline
\end{tabular}

Table 3 has shown the correlations between the subdimensions of the Scale for Rules of Etiquette. It has been seen that the correlation between the subdimensions of the scale and the data is significant.

CFA has been carried out to test the compliance of the Scale for Rules of Etiquette with the data obtained in EFA. The results of CFA have been indicated in Table 4 and Figure 1.

Table 4. Findings of CFA Scale for Rules of Etiquette

\begin{tabular}{|c|c|c|c|c|c|}
\hline Scale & $\chi^{2} / \mathrm{sd}$ & CFI & GFI & AGFI & RMSEA \\
\hline & 1.934 & 0.820 & 0.908 & 0.881 & 0.060 \\
\hline
\end{tabular}

When the findings of CFA shown in Table 4 are examined, it is seen that $\chi^{2} / \operatorname{sd}(228.175 / 118)$ is 1.934 . This value should be below 3 [9]. Other compliance indices achieved with CFA are: $\mathrm{CFI}=0.820$, GFI $=0.908$, $\mathrm{AGFI}=0.881$, RMSEA $=0.060$. RMSEA value is below 0.08; CFI, GFI, and AGFI values are considered to be acceptable to be close to 1 [9]. It has been seen that the model obtained in CFA has good compatibility values.

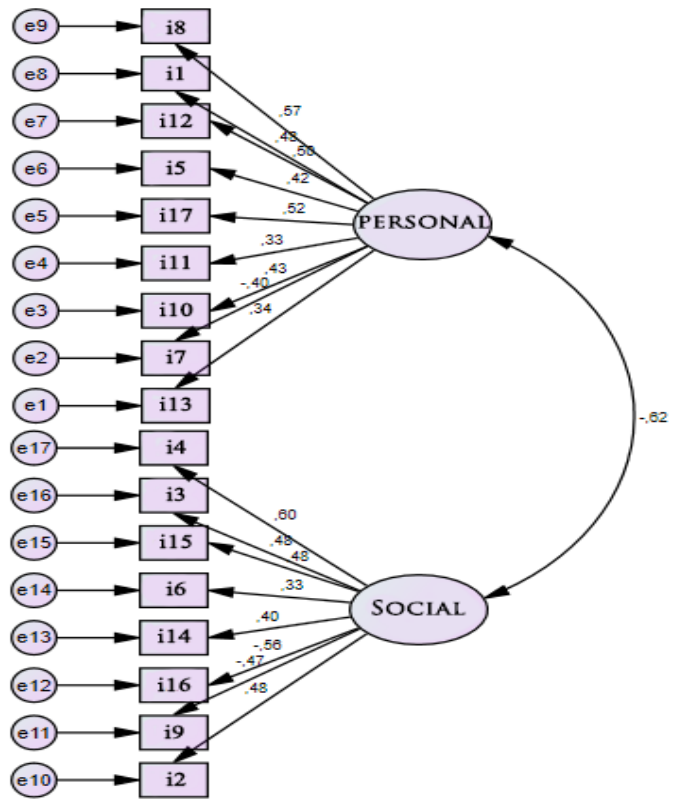

Figure 1. Factor load values of the Scale for Rules of Etiquette

\subsection{Findings Related to Reliability}

The Cronbach Alpha coefficient has been applied to determine the reliability of the Scale for Rules of Etiquette. Cronbach Alpha can be applied to determine the reliability of graded scales such as survey, attitude, interest, alienation, self-esteem, stress, self-efficacy, adoption, anxiety etc. which have answers with two categories (0 or 1) and not continuous [15]. Cronbach Alpha has been estimated as 0.748 in the personal rules sub-dimension and 0.797 in the social rules sub-dimension. The reliability coefficient value accepted in the literature as 0.60. In this case, it can be said that the Scale for Rules of Etiquette is sufficiently reliable. Cronbach alpha is the value that determines the internal consistency of the items in the measure. It is generally recommended that this value be 0.60 and above [2].

\section{Conclusions}

When the literature is examined, it has been stated that there is no scale for etiquette related to Turkish culture. Therefore, this scale has been developed in order to be able to examine the attitudes of the Turkish students who are studying in secondary school to the rules of etiquette.

It has been considered that the data obtained by as a result of the validity and reliability studies of development of the scale for rules of etiquette which has been developed with considering 17 items to determine the attitudes of the Turkish students at secondary school level to the rules of etiquette can be applied in a valid and reliable way. 
In the analysis of the basic components to determine the factor structure of the scale, it has been observed that the scale constituted a 2-factor structure. According to this, the first factor includes 9 items, which is called personal rules and the second factor, which is called social rules, consists of 8 items. These two factors account for $52.25 \%$ of the variance of the scale.

The Cronbach Alpha coefficients for subdimensions of the scale have been estimated as 0.748 in the personal rules subdimension and 0.797 in the social rules subdimension. These values have indicated that the items in the sub-factors are compatible with each other.

In our age, when social development and change accelerate, values rapidly lose their meaning; the contribution of rules of etiquette to the individuals and societies has been understood better, while bringing up new generations that will bring the societies into the future.

\section{Recommendations}

Curriculum changes should be made so that the national and universal culture can be fully reflected in the Turkish language lessons instead of small messages given through the texts.

Audiovisual and kinesthetic activities should be organized so that the rules of etiquette can be accurately and precisely transmitted.

\section{Appendix: Attitude Scale for Rules of Etiquette}

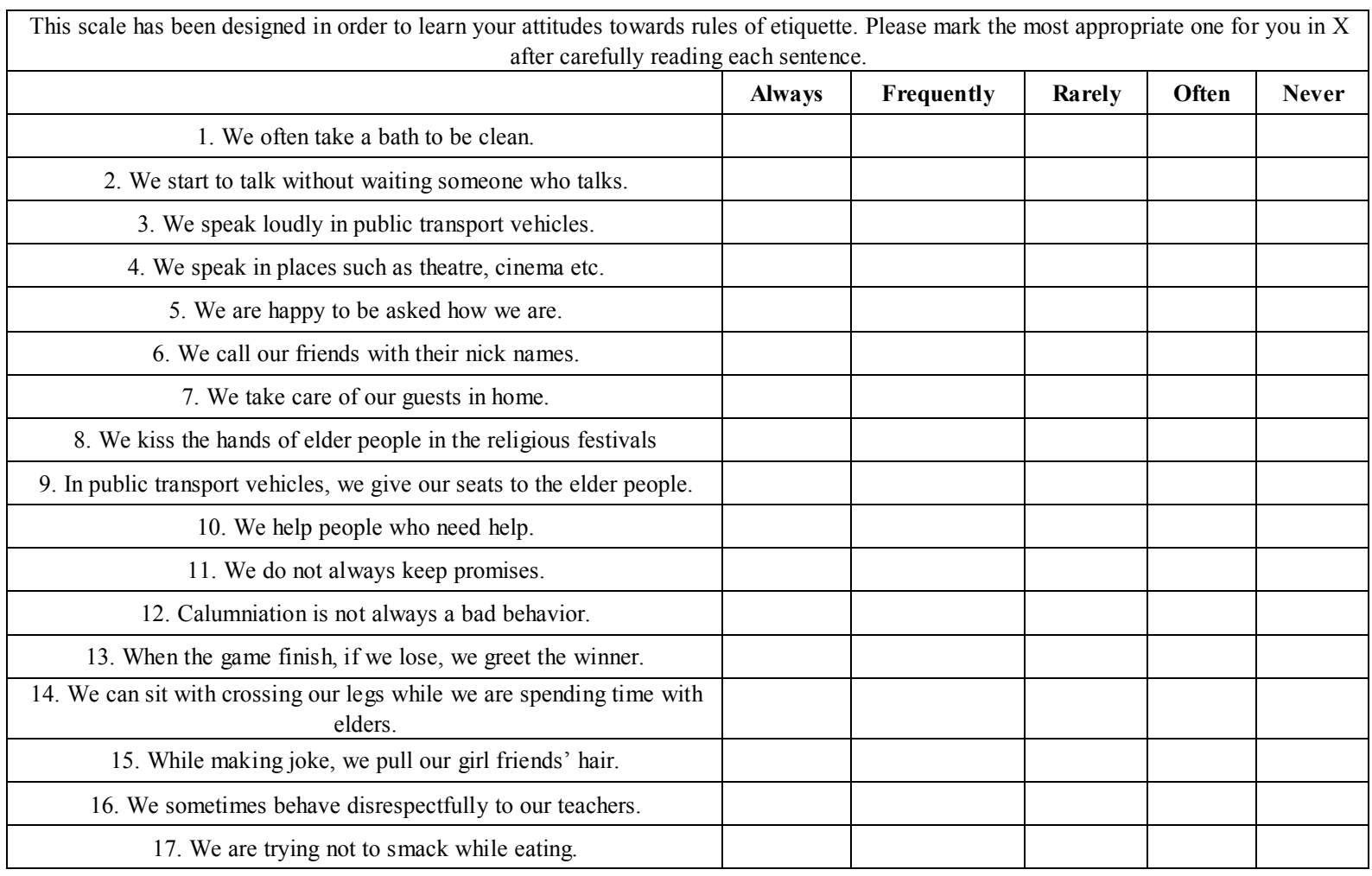




\section{REFERENCES}

[1] Alyılmaz, S. (2008). Öğretmen adaylarına göre görgü kurallarına aykırı davranışlar. İzvestiya, l(2), 136-142.

[2] Albayrak, A. S. vd. (2014). SPSS uygulamalı ve çok değişkenli istatistik teknikleri. (6. bask1). (Ed. Şeref Kalayc1). Ankara: Asil Yayın.

[3] Akbulut, Y. (2010). Sosyal bilimlerde SPSS uygulamalar1. İstanbul: İdeal Kültür.

[4] Andreas, B. (1942). Görgü. (Çev. Turan Aziz Beler). İstanbul: İstanbul Tan Matbaasi.

[5] Atmaca, A. (2010). Gençler için görgü kuralları. (6. Baskı). İstanbul: Nesil Yayınları.

[6] Büyüköztürk, Ş. (2014). Sosyal bilimler için veri analizi el kitabı. Ankara: Pegem Akademi.

[7] Bozkırlı, K. Ç. (2015). Kutadgu Bilig'deki eğitsel ögelerin tespiti ve bu ögelere yönelik Türkçe ögrretmeni adaylarının görüşlerinin incelenmesi. Yayımlanmamış Doktora Tezi, Atatürk Üniversitesi Eğitim Bilimleri Enstitüsü, Erzurum.

[8] Can, F. (2017). Marifetnâme'de yer alan eğitsel unsurlar ve bu unsurlara yönelik Türkçe öğretmeni adaylarının görüşlerinin incelenmesi. Yayımlanmamış Doktora Tezi, Atatürk Üniversitesi Eğitim Bilimleri Enstitüsü, Erzurum.

[9] Karagöz, Y. (2016). SPSS ve AMOS 23 uygulamal istatiksel analizler. Ankara: Nobel Akademik Yayıncılık.

[10] Kurtbay, Y. (1991). Nezaket ve görgü kurallart. Ankara: Kültür Bakanlığ1 Yayınları.

[11] Özaltın, Ş. D. (2007). Her şeyin bir adabı var. İstanbul: Sistem Yayıncılık.

[12] Pallant, J. (2005). SPSS survival manual: a step by step guide to data analysis using SPSS for windows. Australia: Australian Copyright.

[13] Peng, J. (2013). The challenge of measuring willingness to communicate in EFL contexts. Asia - Pacific Edu Res, 22(3), 281-290.

[14] Seçer, I. (2015). SPSS ve LISREL ile pratik veri analizi analiz ve raporlaştırma. (2. Bask1). Ankara: An1 Yaymcilik.

[15] Sönmez, V. \& Alacapınar, F. G. (2014). örneklendirilmiş bilimsel araştırma yöntemleri. (3. Baskı). Ankara: An1 Yayınc1lik.

[16] Söylemez, Y. (2005). Görgüsüzlük çă̆g. Ankara: ODTÜ Yayıncilik.

[17] Tabachnick, B. G. \& Fidel, L. S. (2011). Using multivariate statistics. Boston: Allyn ve Bacon Com.

[18] Türk Dil Kurumu. (2011). Türkçe sözlük. Ankara: TDK Yayınlar1. 